\title{
Path Analysis on the Effect of Hormonal Contraceptive Use on the Risk of Depression in Women of Reproductive Age in Gunungkidul, Yogyakarta
}

\author{
Neta Afriyanti'), Eti Poncorini Pamungkasari²), Hanung Prasetya3) \\ ${ }^{1)}$ Masters Program in Public Health, Universitas Sebelas Maret \\ 2)Faculty of Medicine, Universitas Sebelas Maret \\ ${ }^{3)}$ School of Health Polytechnics, Ministry of Health Surakarta
}

\section{ABSTRACT}

Background: The choice of contraceptive use is based on regulating birth spacing or those who no longer want offspring. Although hormonal contraceptives have been available for more than 50 years, many do not know that hormonal contraceptives also have psychological effects on hormonal contraceptives and their biological mechanisms. This study aims to analyze the effect of hormonal family planning on symptoms of depression in women of reproductive age in Gunungkidul, Yogyakarta.

Subjects and Method: This cross-sectional study was conducted in Gunungkidul, Yogyakarta, from December 2019 to January 2020. A sample of 200 women of reproductive age was selected by purposive sampling. The dependent variable was depression symptoms in women of reproductive age. In contrast, the independent variables were education, age, duration of use, employment status, family income, and hormonal contraceptives. Data were collected using the Beck Depression Inventor II (BDI II) questionnaire and analyzed with path analysis using the Stata 1.3 application.

Results: The incidence of depression symptoms in women of reproductive age increased with duration of use $\geq 36$ months ( $b=1.84 ; 95 \% \mathrm{CI}=$ 0.86 to 2.83 ; $\mathrm{p}<0.001$ ) and contraceptives use $(b=1.31 ; 95 \% \mathrm{CI}=0.47$ to $2.15 ; \mathrm{p}=0.001)$. The incidence of depression symptoms in women of reproductive age decreased with age $\geq 29$ years $(b=-2.05 ; 95 \% \mathrm{CI}=-3.04$ to $-1.07 ; \mathrm{p}=<0.001)$, family income $\geq$ IDR 1,571 ,ooo $(b=-3.06 ; 95 \%$ $\mathrm{CI}=-3.06$ to $-1.41 ; \mathrm{p}<0.001), \geq$ high school education ( $b=-1.67$; CI $95 \%=-2.54$ to $-0.18 ; \mathrm{p}=$ $<0.001$ ), and employment status (work outside the home) (b=-0.98; CI95 \% $=-1.78$ to $-0.18 ; \mathrm{p}=$ o.016).

Conclusion: Duration of use, contraceptive use, age, family income, education, employment status affect depression symptoms in women of reproductive age.

Keywords: hormonal contraceptives, depression symptoms, path analysis

\section{Correspondence:}

Neta Afriyanti. Masters Program in Public Health, Universitas Sebelas Maret, Jl. Ir. Sutami 36 A, Surakarta 57126, Central Java. Email: neta.friyanti16@gmail.com

Cite this as:

Afriyanti N, Pamungkasari EP, Prasetya H (Year). Path Analysis on the Effect of Hormonal Contraceptive Use on the Risk of Depression in Women of Reproductive Age in Gunungkidul, Yogyakarta. J Matern Child Health. 05(06): 651-662. https://doi.org/10.26911/thejmch.2020.05.06.05.

cc (i) (8) Journal of Maternal and Child Health is licensed under a Creative Commons Attribution-Non Commercial-Share Alike 4.o International License.

\section{BACKGROUND}

Uncontrolled population growth negatively impacts the economic sector, the environment, and development efforts both nationally and regionally. Therefore, the key to slowing down population growth is participating in family planning (WHO, 2018). For this reason, the government recommends contraceptives as a method of preventing pregnancy (Herowati and Sugiharto, 2019).

Hormonal contraceptives are the most widely used method of contraception. Although hormonal contraceptives have been 
available for more than 50 years, little is known about the prevalence of mood changes associated with hormonal contraceptives and the underlying biological mechanisms responsible for the changes that occur and their effects on mood (Poromaa and Segebladh, 2012).

The current literature shows the effects of hormonal contraceptives on emotional functions such as fear and stress, relationships between partners, and social acceptance. Neuroimaging research on the hormones estrogen and progesterone predicts that hormonal contraceptives impact emotional reactivity and fear control (Montoya and Bos, 2017). Women themselves have twice the risk of experiencing depression disorders than men (Mcketta and Keyes, 2019)

Low levels of serotonin in the body caused by the hormone progesterone are the cause of depression. Psychological disorders that occur in users of hormonal contraceptives as a psychological side effect. Complaints that arise are somatic complaints, anxiety and the emergence of stressors from the environment (Toffol et al., 2011)

$64 \%$ of women who are married between the ages of 15 and 49 in Indonesia use a contraceptive method, $57 \%$ use a modern contraceptive method and $6 \%$ use a traditional contraceptive method. The trends in the use of family planning that are most widely used by married women are injection (29\%), pills (12\%), implants and IUDs (5\% each) and MOW (4\%) (IDHS, 2017). The data recorded in the Yogyakarta Health Office in 2017 that active contraceptives users of Longterm contraceptive methods/MJKP (IUD, MOP, MOW, Implant) were 36.2\% (149,708 participants) while non-long-term contraceptive methods were $63.8 \%$ (263,492 participants). The most used of family planning was an injection, amounting to $46.8 \%(193,482$ participants).
The number of fertile age couples (PUS) in Gunungkidul is 118,767 people. The new family planning participants were $4.5 \%$ (5,336 people) and active family planning was $77.7 \%$ (92,324 people). The most used contraceptive devices were injections of 58.8\% (54,308 people), IUD 14.1\% (12,992 people), pills $11.9 \%$ (10,979 people), implants 7.9\% (7,320 people, while MOP, MOW and condoms were $7 \cdot 3 \%(6,725$ people) (Gunung kidul Health Office, 2017).

Based on Basic Health Research (2018), the prevalence of depression was 706,689 people $(6.1 \%$ of the total population) in the age range $>15$ years to $75^{+}$years. The prevalence of women experiencing depression was 354,420 people (7.4\%).

\section{SUBJECTS AND METHOD}

\section{Study Design}

This was an analytic observational study with a cross-sectional design. The study was conducted in 5 Independent Practice Midwives (BPM) Gunungkidul, Yogyakarta, from December 2019 to January 2020.

\section{Population and Sample}

This study's population was women of reproductive age aged 20 to 35 years in Gunungkidul, Yogyakarta. A total of 200 subjects were selected by purposive sampling.

\section{Study Variables}

The endogenous variables were family income and age. The exogenous variables were duration of use, hormonal contraceptives, education and occupation.

\section{Operational Definition of Variables}

Age was the age of the study subject at the time of the study. Data were collected using a questionnaire. The continous data was transformed into dichotomous, code $0<29$ years and $1 \geq 29$ years.

Education was the level of formal education that a mother takes to get a diploma. Data were collected using a questionnaire. The measurement scale was categorical, code o 
$<$ Senior High School and $1 \geq$ Senior High School.

Employment status was a statement of the study subject regarding the status of work or not working at the study time. Data were collected by questionnaire. Categorical data scale, code $\mathrm{O}=$ working at home and $1=$ working outside the home.

The duration of use was the length of time the subject used the contraceptives. Data were collected using a questionnaire. Continous data scale, code $0<36$ months and $1 \geq$ 36 months.

Type of contraceptives was the method chosen by the subject, both hormonal contraceptives (pills, injections, and implants) and non-hormonal contraceptives (IUD, condoms, and non-device methods). Data were collected using a questionnaire. The measurement scale was categorical, code $\mathrm{O}=$ nonhormonal and $1=$ hormonal.

Depression symptom was a feeling disorder in which the subject feels deep and continuous sadness, causing behavioral disorders. Data were collected using a questionnaire. Continuous data scale, code $\mathrm{o} \leq$ Score 19 and $1>$ score 19.

During the last six months, family income was income as the cumulative economic source of the nuclear family (husband and wife). Data were collected using a questionnaire. Categorical data scale, code $\mathrm{O}=<\mathrm{UMR}(\mathrm{Rp} 1,571,000)$ and $1=\geq \mathrm{UMR}$ (Rp 1,571,000).

\section{Data Analysis}

Univariate analysis was performed on each study variable. Categorical data were described with a frequency distribution table described in terms of number (n) and percent (\%) parameters. The characteristics of a continous sample of data were described in terms of the parameter number (n), mean, $\mathrm{SD}$, minimum, and maximum. The bivariate analysis used the chi-square test. The multivariate analysis used was Path Analysis using the Stata 1.3 application.

\section{Research Ethic}

This study was conducted based on research ethics, namely, confidentiality, anonymity, informed consent and ethical research. Research ethics was obtained from the Health Research Ethics Committee at Dr. Moewardi, Surakarta, Indonesia, No: 036/I/HREC/ 2020.

\section{RESULTS}

\section{Sample Characteristics}

Table 1 shows the sample characteristics (continuous data) and categorical data as described in Table 2.

Table 1. Sample Characteristics (continuous data)

\begin{tabular}{lccccc}
\hline \multicolumn{1}{c}{ Variable } & N & Mean & SD & Min. & Max. \\
\hline Age & 200 & 28.77 & 4.10 & 20 & 35 \\
Duration of contraceptives use & 200 & 36.28 & 21.79 & 6 & 120 \\
Depression Symptom (BDI) & 200 & 16.51 & 5.74 & 0 & 27 \\
\hline
\end{tabular}

Table 2. Sample characteristics (categorical data)

\begin{tabular}{llcc}
\hline Characteristics & & $\mathbf{N}$ & $\mathbf{\%}$ \\
\hline Education & <Senior High School & 68 & 34 \\
Family income & 2 Senior High School & 132 & 66 \\
& < Regional Minimum Wage (Rp.1,571,000) & 102 & 51 \\
Maternal Occupation & 2 Regional Minimum Wage (Rp.1,571,000) & 98 & 49 \\
\multirow{2}{*}{ Types of contraception } & Working at home & 110 & 55 \\
& Working outside the home & 90 & 45 \\
& Hormonal & 100 & 50 \\
& Non-hormonal & 100 & 50 \\
\hline
\end{tabular}


Afriyanti et al./ the Effect of Hormonal Contraceptive Use on the Risk of Depression

Table 2 shows that the subjects' level of education was mostly more or equal to Senior High School as many as 132 people (66\%). Income $\geq$ Regional Minimum Wage (Rp. $1,571,000)$ as many as 98 people (49\%).

\section{The result of bivariate analysis}

Table 3. Bivariate analysis of the effect of age, duration of use, family income, education, employment status and type of contraceptives using the chi-square

\begin{tabular}{|c|c|c|c|c|c|c|}
\hline \multirow{3}{*}{ Independent Variable } & \multicolumn{4}{|c|}{ Depression Symptom } & \multirow{3}{*}{ OR } & \multirow{3}{*}{$\mathbf{p}$} \\
\hline & \multicolumn{2}{|c|}{ Mild } & \multicolumn{2}{|c|}{ Severe } & & \\
\hline & $\mathbf{N}$ & $\%$ & $\mathbf{N}$ & $\%$ & & \\
\hline \multicolumn{7}{|l|}{ Age } \\
\hline$<29$ years & 39 & 37.14 & 66 & 62.86 & \multirow{3}{*}{0.32} & \multirow{3}{*}{$<0.001$} \\
\hline$\geq 29$ years & 61 & $64 \%$ & 34 & 35.79 & & \\
\hline \multicolumn{5}{|l|}{ Duration of Use } & & \\
\hline$<36$ months & 53 & 61.63 & 33 & 38.37 & \multirow{3}{*}{2.28} & \multirow{2}{*}{0.004} \\
\hline$\geq 36$ months & 47 & 41.23 & 67 & 58.77 & & \\
\hline \multicolumn{6}{|l|}{ Family Income } & \\
\hline$<$ Rp. 1,571,000 & 26 & 25.49 & 76 & 74.51 & \multirow{3}{*}{0.11} & \multirow{3}{*}{$<0.001$} \\
\hline$\geq$ Rp. $1,571,000$ & 74 & 12.8 & 24 & 12.8 & & \\
\hline \multicolumn{5}{|l|}{ Education } & & \\
\hline$<$ Senior High School & 14 & 20.8 & 54 & 11.8 & \multirow{3}{*}{0.13} & \multirow{3}{*}{$<0.001$} \\
\hline$\geq$ Senior High School & 86 & 65.15 & 46 & 34.85 & & \\
\hline Employment Status & & & & & & \\
\hline Working at home & 43 & 39.09 & 67 & 60.91 & \multirow{3}{*}{0.37} & \multirow{3}{*}{$<0.001$} \\
\hline Working outside the home & 57 & 63.33 & 33 & 36.67 & & \\
\hline Type of Contraceptives & & & & & & \\
\hline Non-hormonal & 63 & 63 & 37 & 37 & \multirow{2}{*}{2.89} & \multirow{2}{*}{$<0.001$} \\
\hline Hormonal & 37 & 37 & 63 & 63 & & \\
\hline
\end{tabular}

Table 3 shows the results of the bivariate analysis, age $\geq 29$ years $(\mathrm{OR}=0.32 ; \mathrm{p}$ $<0.001$ ), duration of use $\geq 36$ months (OR= 2.28 ; $\mathrm{p}=0.004)$, family income $\geq$ Rp. $1,571, \mathrm{O}^{-}$ oo ( $\mathrm{OR}=0.11 ; \mathrm{p}=<0.001)$, education level $\geq$ Senior High School $(\mathrm{OR}=0.13$; $\mathrm{p}<0.001)$, working outside the home $(\mathrm{OR}=0.37 ; \mathrm{p}$ $<0.001)$, hormonal contraceptives (OR= 2.89; $\mathrm{p}<0.001)$.

\section{Path Analysis}

The results of the path analysis model were described in Figure 1. Figure 1 shows the direct and indirect correlation between variables. Table 4 shows the path analysis results on the effects between age, duration of use, family income, education, employment status and type of contraceptives.
Subjects who worked outside the home were 90 people (45\%), Subjects who used hormonal birth control were 100 people (50\%). 
Afriyanti et al./ the Effect of Hormonal Contraceptive Use on the Risk of Depression

Figure 1 shows that employment status, education, and duration of use indirectly

affected depression symptoms in women of reproductive age.

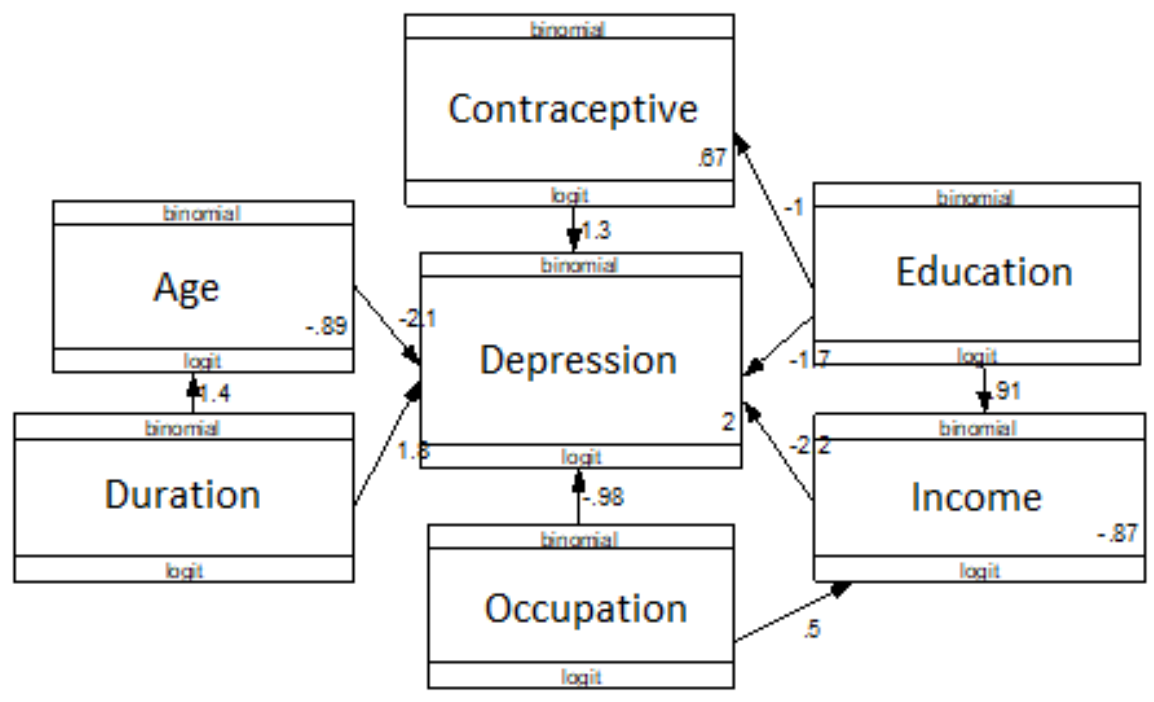

Figure 1. Path analysis the effect of depression symptoms on age, duration of use, family income, education, maternal occupation, and hormonal types

Table 4. The results of the path analysis of the effect between age, duration of use, family income, education, employment status and type of contraceptives

\begin{tabular}{|c|c|c|c|c|c|c|}
\hline \multirow{2}{*}{$\begin{array}{l}\text { Dependent } \\
\text { Variable }\end{array}$} & & \multirow[b]{2}{*}{ Independent Variable } & \multirow[b]{2}{*}{ b } & \multicolumn{2}{|c|}{$95 \%$ CI } & \multirow[b]{2}{*}{$\mathbf{p}$} \\
\hline & & & & $\begin{array}{l}\text { Lower } \\
\text { limit }\end{array}$ & $\begin{array}{l}\text { Upper } \\
\text { limit }\end{array}$ & \\
\hline \multicolumn{7}{|l|}{ Direct effect } \\
\hline $\begin{array}{l}\text { Depression } \\
\text { Symptom }\end{array}$ & $\leftarrow$ & $\begin{array}{l}\text { Employment status (working } \\
\text { outside the home) }\end{array}$ & -0.98 & -1.78 & -0.18 & 0.016 \\
\hline \multirow[t]{5}{*}{ (Severe) } & & Years ( $\geq 29$ years) & -2.05 & -3.04 & -1.07 & $<0.001$ \\
\hline & & Education ( $\geq$ Senior High School) & -1.67 & -2.54 & -0.79 & $<0.001$ \\
\hline & & Hormonal contraceptives & 1.31 & 0.47 & 2.15 & 0.002 \\
\hline & & Family Income ( $\geq$ Rp $1,571,000$ ) & -2.23 & -3.06 & -1.41 & $<0.001$ \\
\hline & $\leftarrow$ & Duration of use ( $\geq 36$ months) & 1.84 & 0.86 & 2.83 & $<0.001$ \\
\hline \multirow{3}{*}{$\begin{array}{l}\text { Indirect effect } \\
\text { Family income } \\
\geq \mathrm{Rp} 1,571,000\end{array}$} & & & & & & \\
\hline & $\leftarrow$ & $\begin{array}{l}\text { Employment status (working } \\
\text { outside the home) }\end{array}$ & 0.50 & -0.07 & 1.07 & 0.088 \\
\hline & & Education ( $\geq$ Senior High School) & 0.90 & 0.29 & 1.52 & 0.004 \\
\hline $\begin{array}{l}\text { Hormonal } \\
\text { contraceptives }\end{array}$ & $\leftarrow$ & Education ( $\geq$ Senior High School) & -1.00 & -1.61 & -0.39 & 0.001 \\
\hline $\begin{array}{l}\text { Age }(\geq 29 \text { years }) \\
\text { N observation }=2 \\
\text { Log likehood }=-47\end{array}$ & $\begin{array}{l}\leftarrow \\
\text { po } \\
2.41\end{array}$ & Duration of use ( $\geq 36$ month) & 1.35 & 0.75 & 1.9 & $<0.001$ \\
\hline
\end{tabular}

\section{DISCUSSION}

1. The Effect of Age on Depression Symptoms

The results showed a direct effect between maternal age and depression symptoms in users of hormonal contraceptives and it was statistically significant. Mothers aged $\geq 29$ years were more likely to experience symptoms of major depression when using hormonal contraceptives than mothers aged $<29$ years $(b=-2.05 ; 95 \% \mathrm{CI}=-3.04$ to $-1.07 ; \mathrm{p}=$ $<0.001)$. 
This is in accordance with the results of a study conducted by Skovuland et al. (2016), which stated a decrease in the risk of depression symptoms in users of hormonal contraceptives as they age. Women in the age range of 20 to 30 years are three times more likely to experience symptoms of depression (Maina et al., 2016). In other studies, it is known that women under 30 years of age are more prone to experience the negative impacts of using hormonal contraceptives than women who are over 30 years of age. The negative psychological effect of contraceptive use has even started for 3 months of use (Lisofsky et al., 2016). So that younger women have a greater chance of experiencing stress, which will lead to depression (Tunurrohmin et al., 2019).

\section{The Effect of Duration of Hormonal Contraceptive Use on Depression Symptoms}

The results showed a direct effect between duration of use and depression symptoms in users of hormonal contraceptives and it was statistically significant. Mothers with a duration of use $\geq 36$ months were more likely to experience severe depression symptoms using hormonal contraceptives than mothers with a duration of use $<36$ months $(b=1.84$; 95\% CI $=0.86$ to $2.83 ; \mathrm{p}<0.001$ )

This is in line with the results of a study conducted by Aulia (2019), which stated that the length of use was related to depression symptoms with $\mathrm{p}=0.018$ and $\mathrm{OR}=2.192$. This means that women who use hormonal contraceptives than two years had the potential to be 2.192 times more likely to experience depression symptoms than nonhormonal. Another study conducted by Fatmawati and Fatmawati (2019) also stated that the longer the use of hormonal contraceptives, the higher the risk of depression symptoms with an $\mathrm{r}$ value of 0.55 .

The length of time using hormonal contraceptives affects the incidence of dep- ression caused by a lack of serotonin levels in the brain. Serotonin functions as a mood regulator or a person's feelings. Several studies have found that a lack of serotonin is responsible for the symptoms of depression (Martini and Fairus, 2017; Natalia, 2014).

A study conducted by Skovlund et al. (2016) stated a correlation between the duration of use and the risk of depression and the use of antidepressants and then a decrease in the incidence of depression after 7 years of use to less than 10 years. Merki-Feld et al. (2017) stated that although hormonal contraceptives allow the improvement of depression symptoms, it can subside after several months of stopping hormonal contraceptives.

\section{The Effect of Education on Depress- ion Symptoms}

The results showed a direct effect between maternal education and depression symptoms in hormonal family planning users and was statistically significant. Mothers with education level $\geq$ Senior High School were less likely to experience severe depression symptoms using hormonal contraceptives than mothers with education $<$ Senior High School $(b=-1.67 ; 95 \% \mathrm{CI}=-2.54$ to $2.15 ; \mathrm{p}$ $<0.0001)$

There is an inverse correlation between education and depression symptoms. This is in line with a study conducted by Faith and Ross in Kranjac (2016), which stated that women who had higher education were at lower risk of experiencing depression symptoms. On the other hand, there is evidence that people with low education have less economic and social resources to successfully cope with mental health problems. Therefore they are more likely to experience depression symptoms (Kranjac, 2016).

Women with lower secondary education are more likely to experience symptoms of depression (Pulgar et al., 2015). A study conducted by Ardoino et al. (2013) stated that a higher level of education has a risk of 
experiencing depression symptoms by 0.8 times lower than that of women with low education. According to Beck in Hall et al. (2015), women with low levels of education also influence risk assessment, planning, social learning, motivation, taking care of themselves, excessive worry, and a lack of perception of pregnancy opportunities, which have an impact on the decision-making process in choosing a contraceptive method.

\section{The Effect of Family Income on Symptoms of Depression}

The results showed a direct effect between family income and symptoms of depression in users of hormonal contraceptives and it was statistically significant. Mothers with family income $\geq$ Rp. 1,571,00o have a lower likelihood of experiencing depression symptoms when using hormonal contraceptives than mothers with family income $<\mathrm{Rp}$ $1,571,000(b=-2.23 ; 95 \% \mathrm{CI}=-3.06$ to -1.41 ; $\mathrm{p}=<0.001)$

Some literature suggests that families with low income and socioeconomic status have become evidence of risk factors for distress (Drapeau, 2012). Economic limitations, economic dependence, household responsibilities, and the lack of access outside the household cause an increased risk of emotional distress for women (Isfandari, 2015). Therefore, it can be presumed that women with prior mood disturbances and distress may be at a higher risk of developing adverse depression symptoms from the use of hormonal contraceptives because women are particularly sensitive to estrogen and progesterone in the brain pathways involved well connected (Bengtsdotter, 2018). Hormonal contraceptives validate the stress response to reduce cortisol levels, which tend to experience depression symptoms more easily than non-hormonal ones (Lewis, 2019).

A study conducted by Farr et al. (2011) states that income influences the relationship between mental stress and contraception.
Women with low family income are more likely to choose to use short-term contraceptives than women with high family income who choose to use long-term contraception. According to Liwang (2018), contraceptives were practical, cheap, easy to reach, and efficient, which was why women prefer to use hormonal contraceptives (injections) rather than IUDs.

\section{The Effect of Employment Status on Depression Symptoms}

The results showed a direct effect between maternal occupation and depression symptoms in hormonal contraceptives users and was statistically significant. Mothers who work outside the home were less likely to experience depression symptoms using hormonal contraceptives than mothers who work at home $(b=-0.98 ; 95 \% \mathrm{CI}=-1.78$ to $0.18 ; \mathrm{p}=0.016$ )

This is in line with a study conducted by Hoshino et al. (2016), which stated that women who only work at home had a greater chance of experiencing depression symptoms than women who work outside the home. In domestic work, the variance in workload and a lack of self-utilization are associated with the occurrence of depression symptoms and unpredictable circumstances in household work.

Domestic work that does not have high standards and work intensity can contribute to women's poor mental health through disruption of distorted sleep and eating patterns and disruption of circadian rhythms (Shepherd-Banigan et al., 2015). According to Wulyani and Sudiajeng in Putri and Sudhana (2013), housework was one of the three main stressors of housewives. The monotonous homework that must be done every day and mostly focuses only on the house triggers isolated situations in housewives so that they tend to be stressors for women themselves.

While there is some evidence to suggest that estradiol levels in contraceptive use can 
modulate attention to stressor exposure, they are more susceptible to experiencing depression symptoms (Graham and Shin, 2018).

According to Scheuringer et al. (2020), even mild negative mood changes were considered stressful by women rather than users who do not experience anxiety disorders. As a result of the pressure from the homework they face. A study conducted by the National Population and Family Planning Board (BKKBN) (2011) stated that occupation is very influential in choosing the type of contraceptives. Working women prefer to use long-term non-hormonal contraceptives because they realize the benefits and uses of women who work at home.

\section{The Effect of Hormonal Contracep- tives on Depression Symptoms}

The results showed a direct effect between the type of hormonal contraceptives and the depression symptoms in users of hormonal contraceptives, and it was statistically significant. Mothers using hormonal contraceptives were more likely to experience depression symptoms using hormonal contraceptives than mothers who used non-hormonal contraceptives $(b=1.31 ; 95 \% \mathrm{CI}=0.47$ to $2.15 ; \mathrm{p}=0.002$ )

This is in line with a study conducted by Martini and Fairus (2017), which stated that hormonal contraceptives had a 3.15 times risk of experiencing depression symptoms compared to non-hormonal users.

Several research findings shed light on the biological mechanisms linking hormonal changes to depression symptoms, including mood and anxiety. First, the hormones estrogen and progesterone affect neurotransmitters' function, especially serotonin, which is associated with depression. Second, progesterone's effect has an impact on the GABA (Gamma Amino Butiric Acid) receptors that regulate a person's anxiety. Third, ovarian hormones influence the stress response, thereby increasing susceptibility to depres- sion symptoms, via the hypothalamic-hypnosis-adrenal axis. Besides, estradiol affects the neurological system associated with fear or anxiety (Cheslack-Postava et al., 2014). Ovarian hormone fluctuations are associated with an increased prevalence of depression symptoms in women (Kuehner, 2017).

The disruption of ovarian hormone production naturally is caused by disruption of serotonin, dopamine, and norepinephrine regulation, which mostly causes depression symptoms as ethylogy. The reduced serotonin is responsible for the incidence of depression symptoms (Natalia, 2014). Then, hormonal contraceptives exacerbate mood swings outside the menstrual period and increase the onset of depression symptoms during the pre-menstrual period. Although statistically significant, the average difference in depression symptoms was small between users of hormonal and non-hormonal contraceptives (Roe et al., 2020). The current literature shows that modern low-dose hormonal contraceptives show less effect on the occurrence of depression symptoms (Pagano et al., 2016).

Large cohort studies have shown that progestin-contraceptives have a greater risk of developing depression symptoms. Still, a systematic review found little evidence of an association between progestin contraceptives and depression (Laird et al., 2019).

According to Laely and Fajarsari in Ramadhan et al. (2017), among the three types of contraceptives that contain progestins (mini pills, DMPA, implants), mini pills have the highest synthetic progesterone content, namely $350 \mathrm{mg}$ norethindrone, then DMPA of $150 \mathrm{mg}$ and implants of $36 \mathrm{mg}$ levonorgestrel (norplan), 68 mg 3-ketodesogestrel (implanon) and $75 \mathrm{mg}$ lenovorgestrel (jadena)

The hormonal components of combined contraceptives have little effect on mood swings and depression symptoms. This is due 
to the difference in lower doses, so it is lower to experience depression symptoms than a single hormone (Schaffir, 2016).

Some studies suggest that estrogen has a role in increasing serotonin levels which has an antidepressant-like effect on the neurotransmitter depominergic neurons, ergikneuron GABA. Therefore, combined hormonal contraceptives may reduce the exacerbation of depression symptoms compared to those containing only the hormone progetin (Smith, 2018).

\section{AUTHOR CONTRIBUTION}

Neta Afriyanti was the main researcher who played a role in data collection, research, research articles, and data processing. Eti Poncorini was involved in the formulation of the background, framework and discussion of research and methodology. Hanung Prasetya helped formulate a theory review and research discussion.

\section{CONFLICT OF INTEREST}

There is no conflict of interest in this study.

\section{FUNDING AND SPONSORSHIP}

This study used personal funds.

\section{ACKNOWLEDGEMENT}

The authors would like to express gratitude to all subjects who have been willing to participate in this study.

\section{REFERENCE}

Ardoino GI, Queirolo EI, Barg G, Ciccariello DA, Kordas K (2013). The relationship among depression, parenting stress, and partner support in low-income women from Montevideo, Uruguay. Health Care Woamen Int., 36(4), 392408. doi:10.1080/07399332.2013.852552.

Bengtsdotter H, Lundin C, Gemzell Danielsson K, Bixo M, Baumgart J, Marions L,
Poromaa IS (2018). Ongoing or previous mental disorders predispose to adverse mood reporting during combined oral contraceptive use. Eur J Contracep Repr. 23(1): 45-51. Doi: 10.1080/13625187.2017.1422239.

BKKBN (2011). Analisis Lanjut: Faktor-faktor yang memengaruhi penggunaan MKJP di enam wilayah Indonesia. Direktorat Teknologi Informasi dan Dokumentasi BKKBN

Cheslack-Postava K, Keyes KM, Lowe SR, Koenen KC (2014). Oral contraceptive use and psychiatric disorders in a nationally representative sample of women. Arch Womens Ment Health, 18(1): 103-111. doi:10.1007/s00737-014-0453-4.

Dinas Kesahatan Kabupaten Gunungkidul (2018). Profil Kesehatan Kabupaten Gunungkidul. Retrieved from https://dinkes.gunungkidulkab.go.id/.

Dinas Kesehatan DIY (2017). Departeman Kesehatan Indonesia. Retrieved from http://www.depkes.go.id/resources/download/profil/PROFIL_KES_PROVINSI_2017/14_DIY_2017.pdf.

Drapeau A, Marchand A, Beaulieu-Prévost D. (2012). Epidemiology of Psychological Distress, Mental Illnesses - Understanding, Prediction and Control, Luciano L'Abate, IntechOpen, doi: 10.5772/30872. Retrieved from: https://www.intechopen.com/books/mental-illnessesunderstanding-prediction-and-control/epidemiology-of-psychological-distress.

Farr SL, Curtis KM, Robbins CL, Zapata LB, dan Dietz PM (2011). Use of contraception among US women with frequent mental distress. Contraception, 83(2): 127-133. doi:10.1016/j.contraception.2010.07.05.

Graham BM, Shin G (2018). Estradiol moderates the relationship between state- 
Afriyanti et al./ the Effect of Hormonal Contraceptive Use on the Risk of Depression

trait anxiety and attentional bias to threat in women. Psychoneuroendocrinology. 93: 82-89. doi:10.1016/j.psyneuen.2018.04.01.

Hall KS, Steinberg JR, Cwiak CA, Allen RH, Marcus SM (2015). Contraception and mental health: a commentary on the evidence and principles for practice. Am J Obstet Gynecol. 212(6): 740-746. doi:10.1016/j.ajog.2014.12.010.

Herowati D, Sugiharto M (2019). Hubungan antara kemampuan reproduksi, kepemilikan anak, tempat tinggal, pendidikan dan status bekerja pada wanita sudah menikah dengan penggunaan kontrasepsi hormonal di indonesia tahun 2017. Buletin Penelitian Sistem Kesehatan. 22(2): 91-98.

Hoshino A, Amano S, Suzuki K, Suwa M (2016). Relationships between Depression and Stress Factors in Housework and Paid Work among Japanese Women. Hong Kong J Occup Th. 27(1): 35-41. doi:10.1016/j.hkjot.2016.03.001

Isfandari S (2015). Penggunaan kontrasepsi hormonal dan distress emosional sebagai kontributor hipertensi perempuan Indonesia: tinjauan perspektif jender. Bul Penelit Kesehat. (43)(1).

Kranjac AW, Niec J, Trevisan M, Freudenheim JL. (2017). Depression and body mass index, differences by education: Evidence from a population-based study of adult women in the U.S. BuffaloNiagara region. Obes Res Clin Pract, 11(1): 63-71. doi:10.1016/j.orcp.2016.03.002.

Kuehner C (2017). Why is depression more common among women than among men?. Lancet Psychiatry. 4(2): 146158. doi:10.1016/s2215-0366(16)30263-2.

Laird S, Ney LJ, Felmingham KL, Gogos A (2019). Hormonal Contraception and the Brain: Examining Cognition and
Psychiatric Disorders. Curr Psychiatry Rep. 15(2): 116-131. doi:10.2174/15734o0515666190521113841.

Lisofsky N, Riediger M, Gallinat J, Lindenberger U, Kühn S (2016). Hormonal contraceptive use is associated with neural and affective changes in healthy young women. NeuroImage. 134: 597606. doi:10.1016/j.neuroimage.2016.04.042.

Lewis CA, Kimmig A-C S, Zsido RG, Jank A, Derntl B, Sacher J (2019). Effects of hormonal contraceptives on mood: a focus on emotion recognition and reactivity, reward processing, and stress response. Curr Psychiatry Rep. 21(11). Doi:10.1007/s11920-019-1095-z.

Liwang F, Bhargah A, Kusuma IBH, Prathiwindya GG, Putra IGIS, Ani LS (2018). Gambaran penggunaan kontrasepsi hormonal dan non hormonal di wilayah kerja UPT Puskesmas Tampak Siring 1. Intisari Sains Medis 2018. 9(3): 41-46. doi: 10.15562/ism.v9i3.301.

Maina G, Mauri M, Rossi A (2016). Anxiety and depression. J Psychol. 22(4): 236250. Retrieved from: Retrieved from: https://www.jpsychopathol.it/wp-content/uploads/2017/O2/O4_Mauri-Maina-Rossi-1.pdf.

Martini M, Fairus M (2017). Penggunaan kontrasepsi hormonal berhubungan dengan penurunan kualitas fisik dan mental sosial akseptor. Jurnal Kesehatan Metro Sai Wawai. 10(2): 90-96. Retrieved from: https://ejurnal.poltekkestjk.ac.id/index.php/JKM.

Mcketta S, Keyes KM (2019). Annals of epidemiology original article oral contraceptive use and depression among adolescents. Ann Epidemiol, 29: 46-51. https://doi.org/10.1016/j.annepidem.2018.10.002.

Merki-Feld GS, Apter D, Bartfai G, Grandi G, Haldre K, Lech M, Lertxundi R, et al. 
Afriyanti et al./ the Effect of Hormonal Contraceptive Use on the Risk of Depression

(2017). ESC expert statement on the effects on mood of the natural cycle and progestin-only contraceptives. Eur J Contracep Repr. 22(4): 247-249. doi: 10.1080/13625187.2017.1353075

Montoya ER, Bos PA (2017). How oral contraceptives impact social-emotional behavior and brain function. Trends Cog Sci. 21(2): 125-136. https://doi.org/10.1016/j.tics.2016.11.005

Natalia ZF (2014). Terapi untuk gangguan depresi dengan psikotik. Referat. Jakarta: Fakultas Kedokteran. Departemen Ilmu Kesehatan Jiwa dan Perilaku Universitas Katolik Indonesia Atma Jaya.

Pagano H, Zapata L, Berry-Bibee E, Nanda K, Curtis K (2016). Safety of hormonal contraception and intrauterine devices among women with depressive and bipolar disorders: a systematic review. Contraception. 94(6): 641-9. https://doi.org/10.1016/j.contraception.2016.06.012.

Poroma IS, Segebladh B (2012). Adverse mood symptoms with oral contraceptives. AOGS. 91: 420-427. https://doi.org/10.1111/j.1600-0412.2011.01333. $\mathrm{x}$

Pulgar CA, Trejo G, Suerken C, Ip EH, Arcury TA, Quandt SA (2016). Economic hardship and depression among women in latino farmworker families. J Immigr Minor Health. 18(3): 497-504. https://doi.org/10.1007/s10903-015-0229-6.

Putri KAK, Sudhana H (2013). Perbedaan tingkat stres pada ibu rumah tangga yang menggunakan dan tidak menggunakan pembantu rumah tangga. Jurnal Psikologi Udayana. 1(1): 94-105. ISSN: 2354-5607.

Ramadhan GS, Mardijana A, Hairrudin (2017). Perbedaan tingkat kecenderungan depresi pada akseptor berbagai jenis kontrasepsi hormonal di Puskes- mas Sumbersari Kabupaten Jember. eJurnal Pustaka Kesehatan. 5(1): 25-29. https://jurnal.unej.ac.id/index.php/JPK/article/view/3867.

Roe AH, Kumar-Kaparaboyna P, Nathan M, Dutton C (2020). Effects of Hormonal Contraception on Mood. Current Obstetrics and Gynecology Reports. 9:3. doi:10.1007/s13669-020-00295-9.

Schaffir J, Worly BL, dan Gur TL (2016). Combined hormonal contraception and its effects on mood: A critical review. Eur J Contracep Repr. 21(5): 347-355. doi:10.1080/13625187.2016.1217327.

Scheuringer A, Lundin C, Derntl B, Pletzer B, Poromaa IS (2020). Use of an estradiol-based combined oral contraceptives has no influence on attentional bias or depressive symptoms in healthy women. Psychoneuroendocrinology, 113: 104544. doi:10.1016/j.psyneuen.2019.104544.

SDKI (2017). Survei Demografi dan Kesehatan Indonesia. Retrieved from: http://sdki.bkkbn.go.id/?lang=id\&what=book Shepherd-Banigan M, Bell JF, Basu A, Booth-LaForce C, Harris JR (2015). Workplace Stress and Working from Home Influence Depressive Symptoms Among Employed Women with Young Children. Int J Behav Med. 23(1): 102111. doi:10.1007/s12529-015-9482-2.

Skovlund CW, Morch LS, Kessing LV (2016). Association of hormonal contraception with depression. JAMA Psychiatry. 73(11): 1154-1162. https://doi.org/10.1001/jamapsychiatry.2016.2387.

Smith K, Nayyar S, Rana T, Archibong A, Looney K, Nayyar T (2018). Do progestin-only contraceptives contribute to the risk of developing depression as implied by betaarrestin 1 levels in leukocytes? A pilot study. Int J Environ Res Public Health. 15(9): 1966. doi:10.339o/ijerph15091966. 
Afriyanti et al./ the Effect of Hormonal Contraceptive Use on the Risk of Depression

Tunurrohmin Z, Soemanto RB, Pamungkasari RP (2019). Path analysis on the determinants of depression symptom In elderly: A precede proceed model. J Epidemiol Commun H 4(4): 351-360. https://doi.org/10.26911/jepublichealth.2019.04.04.10

Toffol E, Heikinheimo O, Koponen P, Luoto R, Partonen T (2011). Hormonal con- traception and mental health: results of a population-based study. Hum Reprod. 26(11): 3085-3093. https://doi.org/10.1093/humrep/der269

WHO (2018). Family planning/ Contraception. Retrieved from: https://www.who.int/news-room/factsheets/detail/family-planning-contraception. 